\title{
Detection and semi-quantification of antibodies to the feline infectious peritonitis virus in cats from the llhéus- Itabuna microregion, Bahia, Brazil
}

\section{Detecção e semiquantificação de anticorpos para o Vírus da Peritonite Infecciosa Felina em gatos da microregião Ilhéus-Itabuna, Bahia, Brasil}

\author{
Jéssica Fontes Veloso'; Leonardo Sauer²; Lohana Mehnati Costa e Silva; \\ Samantha Gusmão Pellizzoni4; Paula Elisa Brandão Guedes"; \\ Renata Santiago Alberto Carlos ${ }^{6 *}$
}

\section{Highlights}

Feline coronavirus is present in cat's population of llhéus-Itabuna microregion.

The seroprevalence of feline coronavirus is low in evaluated population.

The positive animals evaluated did not present clinical alterations.

\begin{abstract}
Feline coronavirus (FCoV) is an important virus that can be differentiated into two serotypes: feline enteric coronavirus (FECoV) and feline infectious peritonitis (FIP) virus (FIPV). Researchers have suggested that a mutation of FECoV to FIPV leads to the emergence of FIP, a disease with worldwide distribution and a high mortality rate. The aim of the present study was to detect and semi-quantify the presence of feline antibodies to FIPV in cats examined at the Veterinary Hospital of Santa Cruz State University, Ilhéus and Itabuna microregion, Bahia, Brazil, between January and April 2018. Blood samples were taken from 68 domestic cats to perform complete blood count $(\mathrm{CBC})$ and biochemical tests, and an indirect fluorescent antibody test (IFAT) was used to detect FCoV infection. Of the 68 samples evaluated, seropositivity was observed in $4.4 \%(3 / 68)$ at titers of $1: 20$; only one sample remained seropositive at titers of $1: 40$ and

1 Prof. Doctor, Undergraduate Course in Veterinary Medicine, Federal University of Western Bahia, UFOB, Barra, BA, Brazil. E-mail: jessica.veloso@ufob.edu.br

2 Master's Student of the Postgraduate Program in Veterinary Clinic, State University of Londrina, UEL, Londrina, PR, Brazil. E-mail: leosauer11@hotmail.com

${ }^{3}$ Student of the Undergraduate Course in Veterinary Medicine, Santa Cruz State University, UESC, Ilhéus, BA, Brazil. E-mail: lohana mehnati@hotmail.com

4 Doctoral Student of the Graduate Program in Animal Science, UESC, Ilhéus, BA, Brazil. E-mail: samantha_pellizzoni@ yahoo.com.br

${ }^{5}$ PhD in Animal Science, Researcher at the National Postdoctoral Program, UESC, Ilhéus, BA, Brazil. E-mail: paulaebg@ gmail.com

6 Prof. Doctor, Undergraduate Course in Veterinary Medicine, UESC, Ilhéus, BA, Brazil. E-mail: rsacarlos@uesc.br

* Author for correspondence
\end{abstract}

Received: June 30, 2020 - Approved: Oct. 23, 2020 
1:80. Two positive animals exhibited $\mathrm{CBC}$ and biochemical values within the normal range, while the other seropositive animals exhibited a mild decrease in platelet count $\left(173,000 \mathrm{uL}^{-1}\right)$, mild lymphocytosis $(7395$ $\left.\mathrm{uL}^{-1}\right)$, and mildly increased alkaline phosphatase level (134 uL-1). Twelve months after the tests, none of the positive animals exhibited clinical signs consistent with FIP. Results of the present study demonstrated that FCoV was present in the population studied, and is an important risk factor for the infection.

Key words: Enteric coronavirus. Felines. Infectious peritonitis. Serology.

\section{Resumo}

O coronavírus felino (FCoV) é um importante vírus que pode ser diferenciado em dois sorotipos: coronavírus entérico felino (FECoV) e vírus da peritonite infecciosa felina (VPIF). Pesquisas sugerem que uma mutação do FECoV para o FIPV leva ao surgimento da peritonite infecciosa felina (PIF). Esta doença possui distribuição mundial e alta taxa de mortalidade. O objetivo desse estudo foi detectar e semiquantificar presença de anticorpos para o FECoV em gatos examinados no Hospital Veterinário da Universidade Estadual de Santa Cruz, microrregião de llhéus e Itabuna, na Bahia, de janeiro a abril de 2018. Foram colhidas amostras de sangue de 68 felinos domésticos para realização de hemograma e testes bioquímicos. Para detecção de FCoV foi utilizada a imunofluorescência indireta (IFI). Das 68 amostras avaliadas, observou-se soropositividade em 4,4\% (3/68) das amostras com títulos de 1:20, e para os títulos 1:40 e 1:80 apenas uma amostra continuou soropositiva. Dois animais positivos apresentaram hemograma e dosagens bioquímicas dentro da normalidade, enquanto o outro animal positivo apresentou discreta diminuição na contagem de plaquetas $\left(173 \mathrm{mil} \mathrm{uL}^{-1}\right)$, discreta linfocitose $\left(7395 \mathrm{uL}^{-1}\right)$ e fosfatase alcalina discretamente aumentada (134 $\left.\mathrm{uL}^{-1}\right)$. Passados doze meses das realizações dos exames, nenhum dos animais positivos apresentou sinais clínicos compatíveis com PIF. A ocorrência encontrada nesse estudo demonstra que há presença do FCoV na população estudada, tornando-se um importante fator de risco para a infecção.

Palavras-chave: Coronavírus entérico. Felinos. Peritonite infecciosa. Sorologia.

\section{Introduction}

Feline infectious peritonitis (FIP) is a disease caused by the FIP virus (FIPV), which belongs to the genus Alphacoronavirus, Coronavirinae subfamily, Coronaviridae family, order Nidovirales (Sparkes, 2006). Coronaviruses have the largest known RNA genome, which exhibits a unique mechanism and is highly susceptible to spontaneous mutation(s) during viral replication, resulting in high genetic diversity (Sparkes, 2006; Pratelli, 2008; Pedersen, 2009; Myhrra et al., 2019; SanJuán \& Domingo-Calap, 2019). Due to this high diversity, there is widespread use of the generic term "feline coronavirus" for all cases of animals infected by both serotypes and biotypes, which can be distinguished by their biological behavior but not their morphology. However, the most appropriate definition implies that the enteric feline coronavirus serotype (FECoV) is the feline coronavirus (FCoV) enteric biotype, and the FIPV serotype originates from mutations of the OFR $3 c$ accessory gene of FCoV (Vennema, Poland, Foley, \& Pedersen, 1998; Hsie et al., 2013). FIPV is considered to be highly virulent and results in the development of FIP disease, which has a high mortality rate in affected animals (Pedersen, 2009). 
FCoV is closely related to the canine coronavirus, swine transmissible gastroenteritis virus, and other coronaviruses of economic impact worldwide (Holmes, 1999). The importance of mutations of this virus has also been highlighted by the emergence of severe acute respiratory syndrome (SARS) in 2002 (Hsu et al., 2003) and Middle Eastern respiratory syndrome (MERS) in 2012 (Zumla, Hui, \& Perlman, 2015). Although FIPV is not considered to be a zoonosis, its high genetic diversity, associated with the lack of knowledge regarding its mutagenic capacity and viral replication, is highly important given the current global coronavirus disease-2019 (COVID-19) pandemic caused by severe acute respiratory syndrome coronavirus 2 (SARSCoV-2), which belongs the same family as FCoV. Domestic cats have been affected by COVID-19, with some exhibiting clinical signs similar to those of humans and even seroconversion of antibodies (Shi et al., 2020).

Transmission of FIPV occurs mainly through nasal secretions, saliva, urine, feces and, although rare, transplacental as well (Sparkes, 2006; Pedersen, Allen, \& Lyons, 2008). FIPV affects cats of all ages, and those who develop FIP can manifest the disease in effusive or non-effusive forms (Pedersen, 2009; Lappin, 2010). Among the most reported clinical signs are jaundice and granulomatous lesions, which can also affect the central nervous system, and pleural effusion, which leads to cardiopulmonary complications (Pedersen, 2009).

To date, definitively diagnosing FIP has been challenging because most diagnostic tests cannot differentiate between the FECoV and FPIV serotypes (Felten \& Hartmann, 2019). Serological analyses, such as the indirect immunofluorescence test (IFAT) and enzyme- linked immunosorbent assay (ELISA), are often used (Pratelli, 2008; Addie et al., 2015), thus enabling antibody titers to be determined as well as immunohistochemistry (Sparkes, 2006; Wang, Hirabayashi, Chambers, Uchida, \& Nakayama, 2018; Felten \& Hartmann, 2019; Sangl et al., 2019). Frequently, however, the diagnosis is presumptive, relying on the association of a positive test, clinical signs, and hyperglobulinemia (Riemer, Kuehner, Ritz, Sauter-Louis, \& Hartmann, 2016; Guan et al., 2020).

In Brazil, Johann et al. (2009) investigated the presence of anti-FCoV serum antibodies of 97 domiciled and non-domiciled cats in Rio Grande do Sul, Brazil, using the serum neutralization test, with positive results in $75.2 \%$ of the animals evaluated. Furthermore, a sero-epidemiological study involving 151 cats was conducted in the city of Botucatu, which reported $64.2 \%$ seropositivity according to ELISA, and was greater than the expected global average (Almeida, Galdino, \& Araújo, 2019).

Thus, due to the proximity of cats and humans, and animals often living in high-density shelters before being adopted by families (thus favoring transmission), and the lack of knowledge of what occurs in terms of mutation if SARS-CoV-2 encounters FECoV, this highlights the importance of understanding the status of the cat population in Brazil with regard to FCoV. In addition, because the prognosis for cats affected by FIP is unfavorable, and the lack of knowledge regarding the presence of positive cats in the region, the present study aimed to detect and semi-quantify feline antibodies to FIPV in cats attending the Veterinary Hospital of the State University of Santa Cruz (UESC), domiciled in the Ilhéus-Itabuna microregion, southern Bahia. 


\section{Materials and Methods}

\section{Ethical considerations}

This study was approved by the Ethics Committee on the Use of Animals from the State University of Santa Cruz, Ilhéus, Bahia, Brazil (protocol 028/2017).

\section{Animals}

The present study included 68 mixedbreed cats domiciled from the routine of the Veterinary Hospital of the State University of Santa Cruz (HOSPVET/UESC), between January and April 2018.

Clinical evaluation and collection of blood samples

Clinical evaluation of the animals in the present study included anamnesis, physical examination, and the collection of $5 \mathrm{~mL}$ of blood from the jugular vein, which was stored in collection tubes with and without EDTA Samples collected in EDTA-containing tubes underwent complete blood count (CBC), and those collected in non-EDTA-containing tubes were centrifuged to obtain serum. Part of the serum was used for biochemical tests, while the other was stored at $-20^{\circ} \mathrm{C}$ until the IFAT was performed at the Veterinary Genetics Laboratory of HOSPVET/UESC.

\section{Hematological and biochemical analyses}

CBC was performed using an automated hematological counter (ABC Vet, Automated Blood Cell Counter, Horiba, Kyoto, Japan). Hematocrit was determined using the micro-hematocrit technique, and leukocyte differential count and platelet count were performed using peripheral blood smears. Biochemical tests included urea, creatinine, alanine aminotransferase, and alkaline phosphatase (ALP) using commercially available kits (Labtest ${ }^{\circledR}$, Labtest Diagnóstica, Lagoa Santa - MG), and reading was performed on a semi-automated analyzer (BIO-2000 $\mathrm{IL}$, Bioplus Produtos para Laboratórios Ltda, Barueri - SP). The total protein value was obtained by analysis using the refractometer. The hematological and biochemical reference values used were those described by Kerr (2003).

\section{IFAT}

Anti-coronavirus antibodies were detected using a commercially available kit (Feline Infectious Peritonitis Virus IFA Antibody Kit, Fuller Laboratories, Fullerton, CA, USA) according to manufacturer's instructions. A 1:20 screening dilution was prepared in phosphate-buffered saline (PBS) for each serum sample according to Kennedy, AbdEldaim, Zika, Mankin and Kania (2008). Fifteen microliters of the serum diluted in PBS was added to each well of the slide. In the tests performed, positive and negative controls were included. The positive control was from a feline with reactive serum titers from 1:20 to $1: 320$ and, for the negative control, a nonreactive serum was used, both provided by the manufacturer. The slides were placed in a humid chamber and incubated for $30 \mathrm{~min}$ at $37 \pm 0.5^{\circ} \mathrm{C}$. Subsequently, the slides were washed three times using a gentle flow of PBS, and the specific species conjugate labeled with fluorescein isothiocyanate was added. The slides were again incubated in a humid 
chamber for 30 min at $37 \pm 0.5^{\circ} \mathrm{C}$, dried, and prepared using mounting medium and cover slip to read the reaction under an epifluorescent microscope (Microscope Scope A.1/AX10 Axion Cam ICc5; Zeiss) at 400× magnification.

Positive reactions were considered to be those that appeared as bright granular fluorescence observed in the cytoplasm of the infected cells. Later, positive samples were diluted to $1: 20,1: 40,1: 80,1: 160$ and 1:320. The size, appearance, and density of the inclusions were compared with the positive and negative control reactions. Reactivity patterns different from those observed in the positive control were considered to be nonspecific.

Results

Of the 68 animals, 40 were female (58.8\%), 28 were male (42.2\%), and all were mixed breed, with ages ranging from 5 months to 12 years. Regarding serology for FECoV, $4.4 \%$ (3/68) were seropositive; 1:20 titers were found in $100 \%(3 / 3)$ of positive samples and 1:40 and $1: 80$ titers in $33.3 \%(1 / 3)$ of samples. The three positive animals were females between five months and three years of age (mean 13.6 months), showed in tables 1 and 2, and none presented clinical signs characteristic of FIP or any other disease on physical examination, being healthy at the time of blood collection.

Only the animal seropositive for the 3 dilutions exhibited a change in platelet count $\left(173,000 \mathrm{uL}^{-1}\right)$ below the normal range for species, in addition to a mild lymphocytosis $\left(7395 \mathrm{uL}^{-1}\right)$ and a mild increase in ALP $\left(134 \mathrm{uL}^{-1}\right)$ - tables 1 and 2.

After 12 months of follow-up, none of these cats exhibited any clinical signs or disease consistent with FIP.

Table 1

Hematological data of domestic cats positive for FECoV by IFAT

\begin{tabular}{ccccccc}
$\begin{array}{c}\text { Animal } \\
(\mathrm{n}=3)\end{array}$ & Age & Gender & Castrated & $\begin{array}{c}\text { Hematocrit } \\
(\%)\end{array}$ & $\begin{array}{c}\text { Leucocytes } \\
\left(\mathrm{uL}^{-1}\right)\end{array}$ & $\begin{array}{c}\text { Platelets } \\
\left(\mathrm{uL}^{-1}\right)\end{array}$ \\
\hline 01 & 5 months & Female & No & 43,5 & 14.500 & 173.000 \\
02 & 3 years & Female & Yes & 37 & 10.700 & 238.000 \\
03 & 3 years & Female & Yes & 36 & 7.300 & 376.000
\end{tabular}

Table 2

Biochemical and serological data of domestic cats positive for FECoV by IFAT

\begin{tabular}{ccccccccc}
$\begin{array}{c}\text { Animal } \\
(\mathrm{n}=3)\end{array}$ & $\begin{array}{c}\text { Urea } \\
(\mathrm{mg} / \mathrm{dL})\end{array}$ & $\begin{array}{c}\text { Creatinine } \\
(\mathrm{mg} / \mathrm{dL})\end{array}$ & $\begin{array}{c}\text { ALT } \\
\left(\mathrm{uL}-\mathrm{-}^{-1}\right)\end{array}$ & $\begin{array}{c}\text { ALP } \\
(\mathrm{uL}-1)\end{array}$ & $\begin{array}{c}\text { Total protein } \\
(\mathrm{g} / \mathrm{dL})\end{array}$ & IFAT 1:20 & IFAT 1:40 & IFAT 1:80 \\
\hline 01 & 45 & 0.8 & 47 & 134 & 7.0 & Positive & Positive & Positive \\
02 & 55 & 2.5 & 68 & 31.2 & 7.6 & Positive & Negative & Negative \\
03 & 57.8 & 1.1 & 48.6 & 43 & 8.0 & Positive & Negative & Negative
\end{tabular}

IFAT = an indirect fluorescent antibody test

ALT= alanine aminotransferase

$A L P=$ alcaline phosphatase. 


\section{Discussion}

The seropositivity rate in the animals described in this study (4.4\%) is important because it demonstrates that there was circulation of FCoV in the feline population in the region studied. This is the third serological investigation of FCoV in Brazil; the two previous studies reported seropositivities > $60 \%$ (Johann et al., 2009; Almeida et al., 2019). The fact that all animals in the present study were domiciled may contribute to the lower rate of positivity compared with the other studies cited, which included non-domiciled and domiciled animals that lived with multiple cats in the same residence. Researchers have concluded that environments with multiple cats confer a higher risk for infection, which applies to non-domiciled cats that live on streets in contact with others, and to homes with $>2$ cats (Almeida et al., 2019). Animals, when living in groups, are more susceptible to infectious diseases and, in the case of FIP, in which the virus is mainly eliminated in the feces, the sharing of hygienic sands or even, in the streets from the places where they defecate, expose these animals to possibly contaminated feces.

All animals in the present study were healthy on physical examination and did not exhibit clinical signs of any disease, although three had antibodies to FCoV. Because these three cats were followed for 12 months and did not exhibit any clinical signs of FIP, this suggests that all these cases were probably caused by the enteric biotype (i.e., FECoV). This is considered to be benign, eventually developing into self-limiting or moderate intestinal alterations (Vogel et al., 2010) that were not reported by any owner. In addition, one of the main laboratory changes in cats with FIP is hyperproteinemia (Felten \& Hartmann, 2019), which was not observed in any of the positive animals, as shown in table 2. Furthermore, considering that one of the consequences of FIP is renal disease, especially in dry FIP (Pedersen, 2009), urea and creatinine were analyzed. However, as can be seen in Table 2, none of the positive animals showed values above the reference for the species. The feline with positive serology at the 1:80 titer and decreased platelet count, contained platelet aggregates. This information is important because the presence of platelet aggregates may be associated with stress due immobilization during blood collection, which may generate false-positive thrombocytopenia (Baker, 2015; Weiser, 2015), despite the cat-friendly practices that were used. Lymphocytosis found as platelets aggregate may also be related to acute containment stress associated with venipuncture, as described by Fam, Rocha, Pimpão and Cruz (2010). Acute stress, caused by pain, fear and transport, causes an increase in catecholamine levels (Fam et al., 2010). After catecholamine secretion, a stress CBC is observed, characterized by neutrophilia, lymphocytosis, and possibly monocytosis and eosinophilia (Nibblett, Ketzis, \& Grigg, 2015). According to Lappin (2010) and Felten and Hartmann (2019), the main hematological parameters found in FIP include anemia, neutrophilic leukocytosis, and lymphopenia. Furthermore, Lappin (2010) reported that thrombocytopenia is related to disseminated intravascular coagulation, which may be related to the non-effusive form and hematological characteristics that were not found in the seropositive animals in the study.

In that same cat, the increase in ALP levels may have occurred due to a mild acute liver disorder, without clinical involvement 
and spontaneous resolution because the cat did not exhibit clinical signs consistent with liver disease, although he was overweight. According to Thrall (2006), elevated ALP levels can indicate liver damage as well as disease(s) that lead to a swelling of hepatocytes, generating greater production and release of ALP, which may explain the slight increase found. The tutor did not return for the review; as such, ultrasound examination to better clarify the process was not performed. However, as previously mentioned, 12 months after the examination, the animal in question did not develop clinical signs consistent with FIP or any other disease.

Althoughitisnotpossibleto differentiate FECoV and FIPV using the IFAT (Felten \& Hartmann, 2019), the prevalence found in this study demonstrates contact of felines with the coronavirus, which may eventually progress to FIP. Given the new COVID-19 pandemic, this type of study in the feline species is even more important, because in the same way that it is suggested that FIP originates from a mutation of the enteric coronavirus (i.e., FECoV), we do not know how it would affect the behavior of SARS-CoV-2 in cats infected with the enteric coronavirus.

\section{Conclusions}

Results of the present study revealed the circulation of FCoV in the feline population in the Ilhéus-Itabuna microregion. Although the IFAT proved to be a complementary diagnostic method, it cannot be regarded a conclusive test for FIP because healthy animals exhibited seroconversion by previous contact with FCoV.

\section{Acknowledgments}

We would like to thank the State University of Santa Cruz (UESC) for offering development conditions for this research as well as for the scientific initiation scholarships and financial aid for the project; Fundação de Amparo à Pesquisa do Estado da Bahia (FAPESB) for financing the project; and this study was also financed in part by the Coordenação de Aperfeiçoamento de Pessoal de Nível Superior - Brasil (CAPES) - Finance Code 001.

\section{References}

Addie, D. D., Poder, S., Burr, P., Decaro, N., Graham, E., Hofmann-Lehmann, R.,... Meli, M. L. (2015). Utility of feline coronavirus antibody tests. Journal of Feline Medicine and Surgery, 17(2), 152-162. doi: $10.1177 / 1098612 \times 14538873$

Almeida, A. C. S., Galdino, M. V., \& Araújo, J. P., Jr. (2019). Seroepidemiological study of feline coronavirus (FCoV) infection in domiciled cats from Botucatu, São Paulo, Brazil. Pesquisa Veterinária Brasileira, 39(2), 129-133. doi: 10.1590/1678-5150PVB-5706

Baker, D. C. (2015). Diagnóstico das anormalidades de hemostasia. In M. A. Thrall, G. Weiser, R. W. Alison, \& T. W. Campbell (Eds.), Hematologia e bioquímica clínica veterinária (2a ed., pp. 399-439). São Paulo: Roca.

Fam, A. L. P. D., Rocha, R. M. V. M., Pimpão, C. T., \& Cruz, M. A. (2010). Alterations on leukogram of domestic felines (Felis catus) due to acute and chronic stress. 
Revista Acadêmica: Ciências Agrárias e Ambientais, 8(3), 299-306. doi: 10.7213/ cienciaanimal.v8i3.10898

Felten S., \& Hartmann, K. (2019). Diagnosis of feline infectious peritonitis: a review of the current literature. Viruses, 11(11), 1-35. doi: 10.3390/v11111068

Guan, X., Li, H., Han, M., Jia, S., Feng, B., Gao, X.,... Xu, Y. (2020). Epidemiological investigation of feline infectious peritonitis in cats living in Harbin, Northeast China from 2017 to 2019 using a combination of an EvaGreen-based real-time RT-PCR and serum chemistry assays. Molecular and Cellular Probes, 49, 1-9. doi: 10.1016/j. mcp.2019.101495

Holmes, K. V. (1999). Coronaviruses (Coronaviridae). Encyclopedia of Virology, 291-298. doi: 10.1006/ rwvi.1999.0055

Hsie, L., Huang, W., Tang, D., Wang, Y., Chen, C., \& Chueh, L. (2013). 3C protein of feline coronavirus inhibits viral replication independently of the autophagy pathway. Research in Veterinary Science, 95(3), 1241-1247. doi: 10.1016/j.rvsc.2013.08. 011

Hsu, L., Lee, C., Green, J. A., Ang, B., Paton, N. I., Lee, L.,... Leo, Y. (2003). Severe acute respiratory syndrome (SARS) in Singapore: clinical features of index patient and initial contacts. Emerging Infectious Diseases, 9(6), 713-717. doi: 10.3201/ eid0906.030264

Johann, J. M., Caetano, C. F., Hass, R., Guim, T. N., Fischer, G., Vargas, G. D.,... Hübner, S. O. (2009). Serum survey for antibodies to coronavirus, herpesvirus, calicivirus, and parvovirus in domestics cats from Rio Grande do Sul, Brazil. Arquivo Brasileiro de Medicina Veterinária e Zootecnia, 61(3), 752-754. doi: 10.1590/S010209352009000300033

Kennedy,M.A.,Abd-Eldaim,M.,Zika,S.E.,Mankin, J. M., \& Kania, S. A. (2008). Evaluation of antibodies against feline coronavirus $7 \mathrm{~b}$ protein for diagnosis of feline infectious peritonitis in cats. American Journal of Veterinary Research, 69(9), 1179-1182. doi: 10.2460/ajvr.69.9.1179

Kerr, M. (2003). Exames laboratoriais em medicina veterinária - bioquímica clínica e hematologia (2a ed.). São Paulo: Roca.

Lappin, M. R. (2010). Doenças infecciosas. In R. W. Nelson, \& C. G. Couto, Medicina interna de pequenos animais (4a ed., pp. 133942). Rio de Janeiro: Elsevier.

Myhrra, L. W., Silva, F. M. F., Vidigal, P. M. P., Resende, M., Bressan, G. C., Fietto, J. L. R.,... Almeida, M. R. (2019). Feline coronavirus isolates from a part of Brazil: insights into molecular epidemiology and phylogeny inferred from the 7b gene. The Journal of Veterinary Medical Science, 81(10), 14551460. doi: 10.1292/jvms.19-0090

Nibblett, B. M., Ketzis, J. K., \& Grigg, E. K. (2015). Comparison of stress exhibited by cats examined in a clinicversus a home setting. Applied Animal Behaviour Science, 173, 68-75. doi: 10.1016/j.applanim. 2014.10.005

Pedersen, N. C. (2009). A review of feline infectious peritonitis virus infection: 19632008. Journal of Feline Medicine and Surgery, 11(4), 225-258. doi: 10.1016/j. jfms.2008.09.008

Pedersen, N. C., Allen, C. E., \& Lyons, L. A. (2008). Pathogenesis of feline enteric coronavirus infection. Journal of Feline Medicine and 
Surgery, 10(6), 529-541. doi: 10.1016/j. jfms.2008.02.006

Pratelli, A. (2008). Comparison of serologic techniques for detection of antibodies against feline coronaviruses. Journal of Veterinary Diagnostic Investigation, 20(1), 45-50. doi: 10.1177/1040638708 02000108

Riemer, F., Kuehner, K. A., Ritz, S., Sauter-Louis, C., \& Hartmann, K. (2016). Clinical and laboratory features of cats with feline infectious peritonitis - a retrospective study of 231 confirmed cases (20002010). Journal of Feline Medicine and Surgery, 18(4), 348-356. doi: 10.1177/ $1098612 \times 15586209$

Sangl, L., Matiasek, K., Felten, S., Gründl, S., Bergmann, M., Balzer, H.,... Hartmann, K. (2019). Detection of feline coronavirus mutations in paraffin-embedded tissues in cats with feline infectious peritonitis and controls. Journal of Feline Medicine and Surgery, 21(2), 133-142. doi: 10.1177/ $1098612 X 18762883$

SanJuán, R., \& Domingo-Calap, P. (2019). Genetic diversity and evolution of viral populations. Reference Module in Life Sciences, 1-9. doi: 10.1016/B978-0-12809633-8.20958-8

Shi, J., Wen, Z., Zhong, G., Yang, H., Wang, C. Liu, R.,... Bu, Z. (2020). Susceptibility of ferrets, cats, dogs, and different domestic animals to SARS-coronavirus-2. Science, 368(6494), 1-10. doi: 10.1126/science.ab b7015
Sparkes, A. H. (2006). Infecção por coronavírus felino. In E. A. Chandler, C. J. Gaskell, \& R. M. Gaskell (Eds.), Clínica e terapêutica em felinos (3a ed., pp. 508-518). São Paulo: Roca.

Thrall, M. A. (2006). Hematologia e bioquímica clínica veterinária. São Paulo: Roca.

Vennema, H., Poland, A., Foley, J., \& Pedersen, N. C. (1998). Feline infectious peritonitis viruses arise by mutation from endemic feline enteric coronaviruses. Virology, 243(1), 150-157. doi: 10.1006/viro.1998. 9045

Vogel, L., Van der Lubben, M., Lintelo, E. G., Bekker, C. P. J., Geerts, T., Schuijff, L. S.,... Rottier, P. J. M. (2010). Pathogenic characteristics of persistent feline enteric coronavirus infection in cats. Veterinary Research, 41(71), 1-12. doi: 10.1051/ vetres/2010043

Wang, H., Hirabayashi, M., Chambers, J. K., Uchida, K., \& Nakayama, H. J. (2018). Immunohistochemical studies on meningoencephalitis in feline infectious peritonitis (FIP). The Journal of Veterinary Medical Science, 80(12), 1813-1817. doi: 10.1292/jvms.18-0406

Weiser, G. (2015). Tecnologia laboratorial em medicina veterinária. In M. A. Thrall, G. Weiser, R. W. Alison, \& T. W. Campbell (Eds.), Hematologia e bioquímica clínica veterinária (2a ed., pp. 22-305). São Paulo: Roca.

Zumla, A., Hui, D. S., \& Perlman, S. (2015). Middle East respiratory syndrome. Seminar, 386, 995-1007. doi: 10.1016/S0140-6736(15) 60454-8 
